\title{
BERPIKIR KOMBINATORIK MATEMATIS SISWA DALAM MENGKONSTRUKSI KONSEP PELUANG
}

\author{
Jepri Igo Budi Handoko', Eko Nisfu Umar Singgih ${ }^{2}$, Wharyanti Ika Purwaningsih ${ }^{3}$ \\ jepriigobudihandoko@gmail.com, esinggiheko@gmail.com, wharyanti@umpwr.ac.id \\ ${ }^{1,2}$ Bimbingan Belajar GAMA International \\ ${ }^{3}$ Pendidikan Matematika, Universitas Muhammadiyah Purworejo
}

\begin{abstract}
This qualitative research aims to describe activity of students mathematical combinatorial thinking in constructing of the opportunity concept. The subject of the study is two students of Junior High School who had the ability in constructing concept. Data collection was obtained at the time of learning carried out based on learning plan as research instruments. The results showed a combinatorial thinking activity in constructing concepts. Counting processes are showen by students identifying dice and coins, solving theoritical opportunities problems with tables or diagrams, and solving empirical opportunities problems. Formulas/exspressions are showen by students being able to construct sampel points and sample space, construct theoritical opportunities concept, and make mathematical formulas of opportunities. Set of outcomes is showen by students being able to find the results of solving theoritical opportunity problems of one/or more dice and coins as well as the results of solving empirically opportunity problems.
\end{abstract}

Keywords: combinatorial thinking, constructing concept, opportunity

\begin{abstract}
Abstrak
Penelitian kualitatif ini bertujuan untuk mendeskripsikan aktivitas berpikir kombinatorik matematis siswa dalam mengkonstruksi konsep Peluang. Subjek dalam penelitian ini adalah dua siswa SMP yang memiliki kemampuan dalam mengonstruksi konsep. Pengumpulan data diperoleh pada saat pembelajaran yang dilaksanakan berdasarkan Rencana Pelaksanaan Pembelajaran (RPP) sebagai instrumen penelitian. Hasil penelitian menunjukan adanya aktivitas berpikir kombinatorik dalam mengkonstruksi konsep. Counting processes ditunjukkan dengan siswa mengidentifikasi dadu dan koin, menyelesaikan masalah peluang teoritik dengan bantuan tabel/diagram, dan menyelesaikan masalah peluang secara empirik. Formulas/exspressions ditunjukkan dengan siswa mampu mengkonstruk titik sampel dan ruang sampel, mengkonstruk peluang secara teoritik, serta membuat rumus matematis dari peluang. Set of outcomes ditunjukkan dengan siswa mampu menemukan hasil penyelesaian peluang teoritik dari satu/atau lebih dadu dan koin serta hasil penyelesaian masalah peluang empirik.
\end{abstract}

Kata kunci: berpikir kombinatorik, mengkonstruksi konsep, peluang 


\section{PENDAHULUAN}

Kemampuan kognitif manusia akan selalu berkembang dari lahir sampai dewasa. Tahap perkembangan berpikir menurut Piaget dalam Ibda (2015) dibagi menjadi empat tahap, yaitu sensori-motor, pra-operasional, operasional konkrit, dan operasional formal. Berdasarkan pendapat tersebut diketahui bahwa tahapan lanjutan dari perkembangan kognitif manusia adalah tahapan operasional formal, dengan kemampuan berpikir kombinatorik merupakan tingkatan tertinggi dari tahapan operasional formal (Widiyastuti \& Utami, 2017). Kemampuan berpikir kombinatorik sangat penting karena merupakan kemampuan dasar yang harus dimiliki untuk dapat memecahkan masalahmasalah matematika. Shin \& Steffe dalam Shulhany (2016) menyatakan bahwa topic terkait penalaran kombinatorial tidak mendapat banyak perhatian dari para peneliti meskipun penalaran kombinatorial terkait erat dengan proses pembuktian atau penentuan dan pengambilan strategi dalam memecahkan masalah-masalah matematika. "Combinatorial thinking is a process to find some alternative solution of discrete problems" (Syahputra, 2016), bahwa berpikir kombinatorial merupakan suatu proses menemukan sejumlah alternative penyelesaian suatu masalah diskrit. Graumann dalam Rezaie \& Gooya (2011) juga mengungkapkan "combinatorial thinking is a special aspect of mathematical thinking", yang artinya berpikir kombinatorik adalah aspek khusus dari berpikir matematika. Lockwood (2013) mengilustrasikan berpikir kombinatorial siswa ke dalam model berpikir kombinatorial siswa.

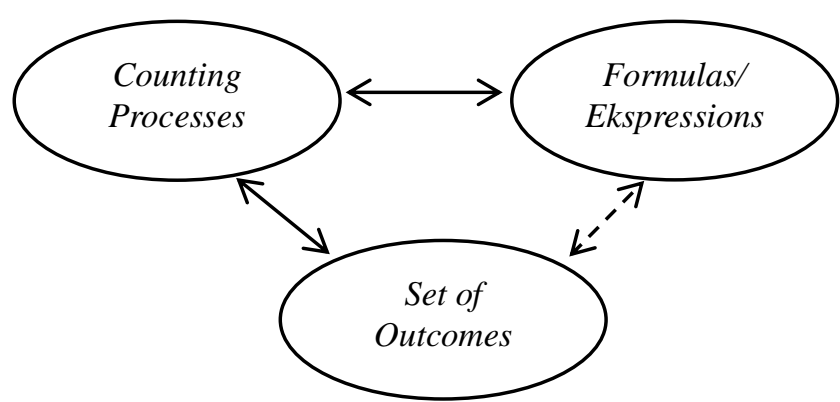

Gambar 1. Model Berpikir Kombinatorial Siswa

Model of students combinatorial thinking, highlighting relationships between formulas/expressions, counting processes, and sets of outcomes. I explicate the components of the model and discribe the ways in which these components interact with one another (Lockwood, 2013). Berdasarkan pendapat tersebut, menunjukkan bahwa dalam model berpikir kombinatorik terdapat hubungan antara komponen-komponen dari 
model berpikir kombinatorial siswa, yaitu proses penghitungan, rumus/ungkapan, dan hasil. Kemampuan berpikir kombinatorik siswa dapat dikembangkan dalam proses pembelajaran. Oleh sebab itu pentingnya mempelajari berkaitan dengan kemampuan berpikir kombinatorik siswa dalam proses pembelajaran.

Proses pembelajaran matematika tidak hanya memahami masalah, menemukan penyelesaian dan menyelesaikan masalah, tetapi diharapkan siswa mampu membangun atau mengkonstruksi pengetahuan mengenai masalah oleh pengalaman yang dimilikinya dalam proses berpikir. Berdasarkan teori konstruktivisme, siswa secara aktif membangun sendiri pengetahuannya.Tasker dalam Hamzah (2008) mengemukakan tiga pendekatan dalam teori belajar konstruktivisme, yaitu peran aktif siswa dalam mengkonstruksi pengetahuan, membuat kaitan antara pengetahuan dan pengkonstruksian pengetahuan, dan mengaitkan gagasan dan informasi baru. Penelitian yang relevan dengan penelitian ini adalah penelitian yang dilakukan oleh Ahmad Shulhany (2016) dengan judul "Daya Kombinatorial Siswa pada Materi Peluang dengan Model Penemuan Terbimbing”. Hasil penelitian ini menunjukkan bahwa kualitas dan daya peningkatan daya kombinatorial siswa yang mendapatkan pembelajaran dengan penemuan terbimbing mendapatkan hasil yang tinggi. Peningkatan kemampuan berpikir kombinatorial siswa yang mendapatkan pembelajaran dengan model penemuan terbimbing lebih baik daripada siswa yang mendapatkan pembelajaran dengan model ekspositori. Mengacu pada penelitian tersebut, tujuan penelitian ini adalah untuk mendeskripsikan aktivitas berpikir kombinatorik matematis siswa dalam mengkonsturksi konsep Peluang.

\section{METODE PENELITIAN}

Penelitian ini merupakan penelitian kualitatif dengan pendekatan fenomenologis. Penelitian kualitatif yang bertujuan untuk memahami fenomena tentang apa yang dialami oleh subjek penelitiannya, misalanya perilaku, persepsi, motivasi, tindakan dan lain-lain secara teoristik dan dengan cara deskripsi dalam bentuk kata-kata dan bahasa, pada suatu konteks khusus yang alamiah dan dengan memanfaatkan berbagai metode ilmiah (Moleong, 2016). Manen dalam Creswell (2017) mengemukakan bahwa tujuan utama dari fenomenologi adalah untuk mereduksi pengalaman individu pada fenomena menjadi deskripsi tentang esensi atau intisari universal. Subjek dalam penelitian ini 
diperoleh berdasarkan pertimbangan (purposive) yaitu siswa yang mampu mengkonstruksi konsep pada materi Peluang. Instrumen utama penelitian ini adalah peneliti sendiri sebagai human instrument dan Rencana Pelaksanaan Pembelajaran (RPP) sebagai acuan pelaksanaan pembelajaran mengkonstruksi konsep. Pengumpulan data dalam penelitian ini menggunakan catatan lapangan, rekaman video pembelajaran, dan wawancara. Teknik analisis data yang digunakan mengacu pada teknik analisis Miles \& Hubermen (Satori \& Komariah, 2017) meliputi kegiatan reduksi, penyajian data, dan penarikan kesimpulan.

\section{HASIL PENELITIAN}

\section{SubjekPertama}

Kegiatan pembelajaran mengkonstruksi konsep Peluang yang pertama adalah mengidentifikasi dadu dan koin, aktivitas berpikir kombinatorik yang muncul adalah counting processes, hal ini ditunjukkan dengan $\mathrm{S}_{3}$ mengamati, menghitung dan berdiskusi mengenai dadu dan koin seperti di tunjukkan dengan gambar berikut.

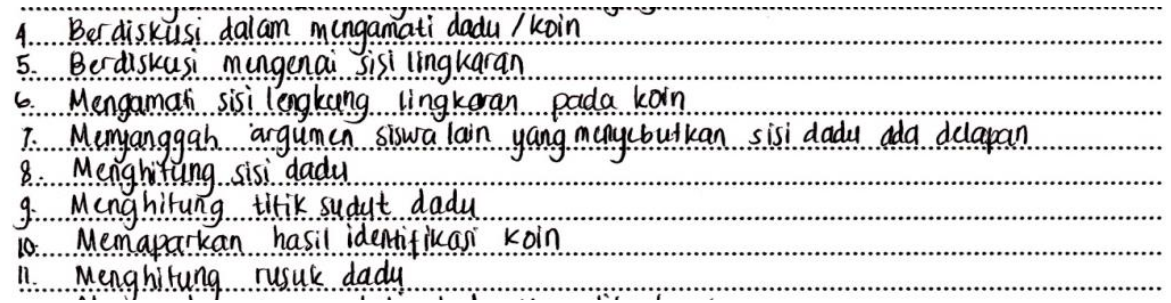

Gambar 2. Catatan Lapangan $\mathrm{S}_{3}$

Berdasarkan gambar tersebut menunjukkan $\mathrm{S}_{3}$ melakukan kegiatan mengidentifikasi dadu/koin dengan cara berdiskusi, kemudian mengamati sisi dadu/koin dan menghitung jumlah sisi, titik sudut, dan rusuk dari dadu dan koin, hal tersebut menujukkan aktivitas berpikir kombinatorik yaitu counting processes.

Selanjutnya dalam kegiatan memaparkan hasil identifikasi dadu dan koin $\mathrm{S}_{3}$ menunjukkan aktivitas berpikir kombinatorik yaitu counting processes-set of outcomes. Hal tersebut ditunjukkan pada cuplikan percakapan berikut.

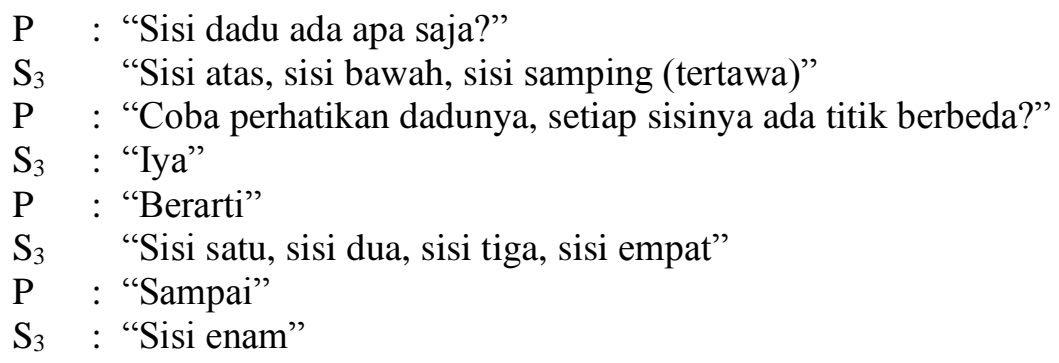


Dalam percakapan pada proses pembelajaran tersebut menunjukkan bahwa $S_{3}$ sudah memahami hasil identifikasi dari dadu dan koin, hal tersebut menunjukkan adanya keterkaitan antara proses menghitung dari kegiatan mengidentifikasi dengan hasil identifikasi atau dalam model berpikir kombinatorik yaitu counting processes-set of outcomes.

Dalam kegiatan mengkonstruk titik sampel dan ruang sampel, aktivitas berpikir kombinatorik yang muncul adalah set of outcomes-formulas/exspressions. Hal tersebut ditunjukkan pada catatan lapangan berikut ini.

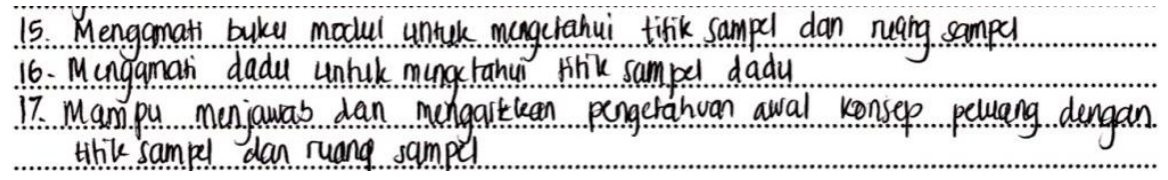

Gambar 3. Catatan Lapangan $\mathrm{S}_{3}$

Gambar tersebut menujukkan $S_{3}$ menghubungkan antara hasil pada kegiatan mengidentifikasi dadu dan koin dengan informasi pada buku mengenai titik sampel dan ruang sampel sebagai bentuk dari formulas/exspressions. Selanjutnya dalam megkonstruk konsep peluang secara teoritik ditunjukkan dengan percakapan pembelajaran sebagai berikut.

P : "Dari peluang $\frac{1}{6}, \frac{1}{6}, \frac{1}{2}$ yang kalian pahami, satu itu apa?"

$\mathrm{S}_{3} \quad$ : "Peluangnya"

$\mathrm{P} \quad$ : "Peluangnyakan $\frac{1}{6}, \frac{1}{6}, \frac{1}{2}$, angka satunya sendiri?"

$\mathrm{S}_{3}$ : "Yang didapat"

P : "Kalau dua dalam koin berarti?"

( $\mathrm{S}_{2}$ dan $\mathrm{S}_{3}$ menjawab "Jumlah sisi")

P : "Jadi peluangnya adalah?"

Berdasarkan percakapan tersebut menunjukkan $\mathrm{S}_{3}$ menggunakan aktivitas berpikir kombinatorik yaitu set of outcomes-formulas/exspressions. Hal tersebut ditunjukkan dengan $\mathrm{S}_{3}$ mengkaitkan hasil-hasil dari percobaan pelemparan dadu/koin dengan konsep peluang yaitu yang dipeloreh banding jumlah sisi. Dalam kegiatan menyelesaikan masalah peluang teoritik dari satu/atau lebih dadu/koin. Berikut ini hasil lembar kerja $S_{3}$ dalam menyelesaikan masalah peluang teoritik dengan bantuan tabel/diagram. 


\begin{tabular}{|c|c|c|c|c|c|c|}
\hline & (1) & (2) & (3) & (4) & (5) & (b) \\
\hline (1) & 1.1 & 1.2 & 3.1 & A. 1 & 5.1 & 6,1 \\
\hline (2) & 2,1 & $2 \cdot 2$ & 3.2 & 4.2 & 5.2 & 6,2 \\
\hline (3) & 3.1 & 2.3 & 3.3 & 4.3 & 5.3 & 6.3 \\
\hline (4) & 4,1 & 2.4 & 3,4 & 4.4 & 5.4 & 6,4 \\
\hline (5) & 5,1 & 2,5 & 3.5 & 4.5 & 5,5 & 6.5 \\
\hline (6.) & b. 1 & 2,6 & 3.6 & 4.6 & $5 \cdot 6$ & 6.6 \\
\hline
\end{tabular}

Gambar 4. Hasil Lembar Kerja $\mathrm{S}_{3}$

Tebel tersebut menunjukkan $\mathrm{S}_{3}$ mampu menggunakan aktvitas berpikir kombinatorik counting processes. $\mathrm{S}_{3}$ mampu mengisi tabel tersebut dengan cara menghitung, hal tersebut diperkuat dengan catatan lapangan sebagai berikut.

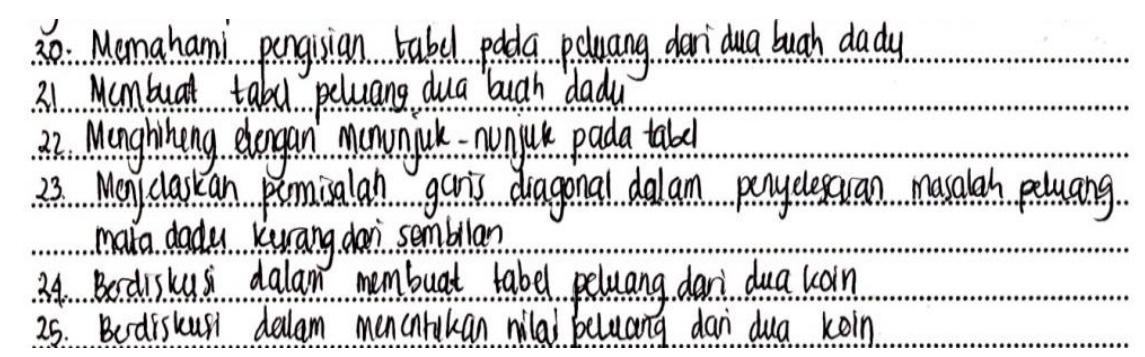

Gambar 5. Catatan Lapangan $S_{3}$

Berdasarkan catatan lapangan tersebut menunjukkan $\mathrm{S}_{3}$ menghitung dengan menunjuknunjuk tabel hal ini menunjukkan $S_{3}$ melakukan aktivitas berpikir kombinatorik yaitu counting processes. Selanjutnya dalam menyelesaikan masalah peluang teoritik dari satu/atau lebih dadu atau koin $S_{3}$ menunjukkan aktivitas berpikir kombinatorik yaitu counting processes-set of outcomes. Hal ini ditunjukkan dengan percakapan pembelajaran sebagai berikut.

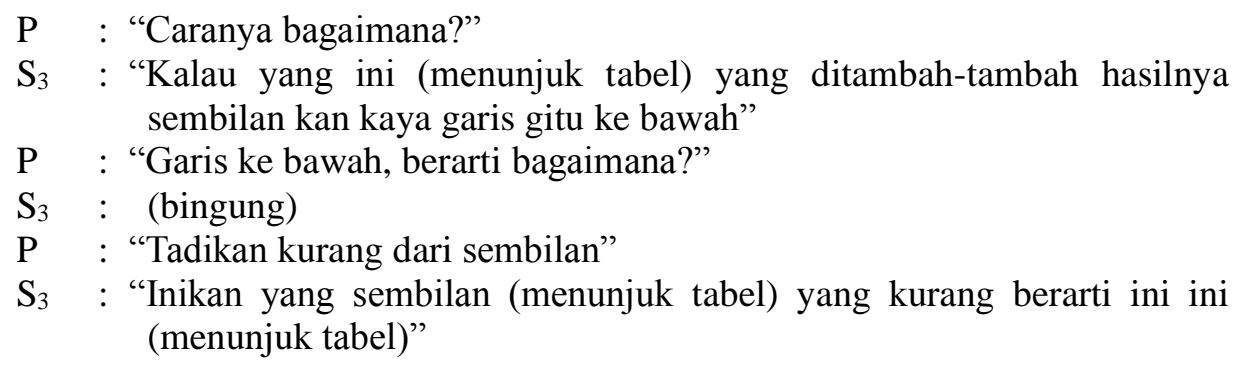

Berdasarkan percakapan tersebut menunjukkan $S_{3}$ menyelesaikan masalah peluang teoritik yaitu peluang muncul mata dadu kurang dari sembilan, $S_{3}$ menghitung pada tabel dan diperoleh hasil dari penyelesaian masalah tersebut. 


$$
\text { Jumlat dadu }<9=\frac{27}{36}
$$

Gambar 6. Hasil Lembar Kerja $\mathrm{S}_{3}$

Gambar tersebut menunjukkan adanya aktivitas berpikir kominatorik yaitu counting processes-set of outcomes. Selanjutnya dalam menyelesaikan masalah peluang empirik, kegiatan yang dilakukan adalah melakukan pelemparan dadu dan koin sebanyak sepuluh kali, sehingga diperoleh hasil sebagai berikut.

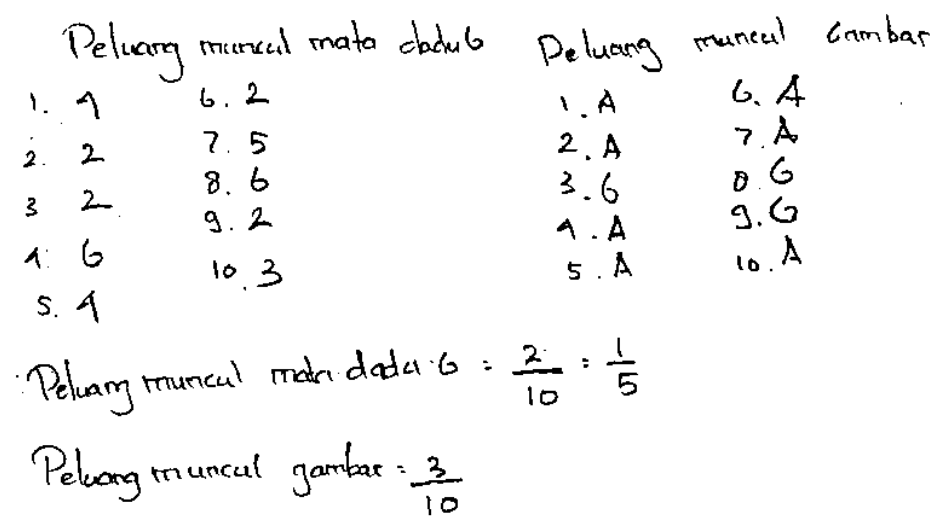

Gambar 7. Hasil Lembar Kerja $\mathrm{S}_{3}$

Berdasarkan gambar tersebut menunjukkan adanya aktivitas berpikir kombinatorik yaitu counting processes-set of outcomes. Counting processes ditunjukkan dengan $\mathrm{S}_{3}$ melakukan proses penghitungan dari hasil pelemparan dadu/koin sehingga diperoleh hasil penyelesaian masalah peluang emipik yang merupakan representasi dari set of outcomes. Selanjutnya dalam kegiatan membuat kesimpulan/generalisasi dari konsep peluang menunjukkan aktivitas berpikir kombinatorik yaitu formulas exspressions dengan ditunjukkkan pada gambar berikut.

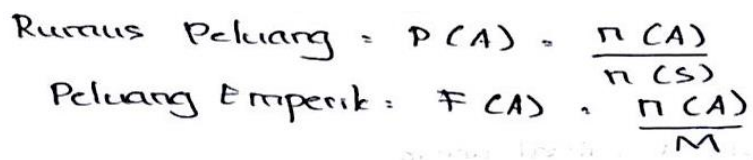

Gambar 8. Hasil Lembar Kerja $\mathrm{S}_{3}$

Gambar tersebut menunjukkan $\mathrm{S}_{3}$ mampu membuat rumus matematis dari Peluang, hal ini diperkuat dengan cuplikan wawancara berikut ini.

$\mathrm{P} \quad$ : "Ini peluang empirik (menunjuk) F(A) sama dengan n(A) per M, M nya apa?"

$\mathrm{S}_{3} \quad$ : "Ruang sampel"

$\mathrm{P} \quad$ : "Bukan ruang sampel! jumlah?" 


$$
\mathrm{S}_{3} \quad \text { : "Percobaan" }
$$

Cuplikan wawancara tersebut menunjukkan aktivitas berpikir kombinatorik yaitu formulas/exspressions, rumus matematis yang dibuat oleh $\mathrm{S}_{3}$ dipeoleh berdasarkan pengetahuan yang dimiliki sebelumnya mengenai konsep Peluang.

\section{Subjek Kedua}

Kegiatan pembelajaran mengkonstruksi konsep Peluang yang pertama adalah mengidentifikasi dadu dan koin, aktivitas berpikir kombinatorik yang muncul adalah counting processes, hal ini ditunjukkan dengan $\mathrm{S}_{9}$ mengamati, menghitung dan berdiskusi mengenai dadu dan koin seperti di tunjukkan dengan gambar berikut.

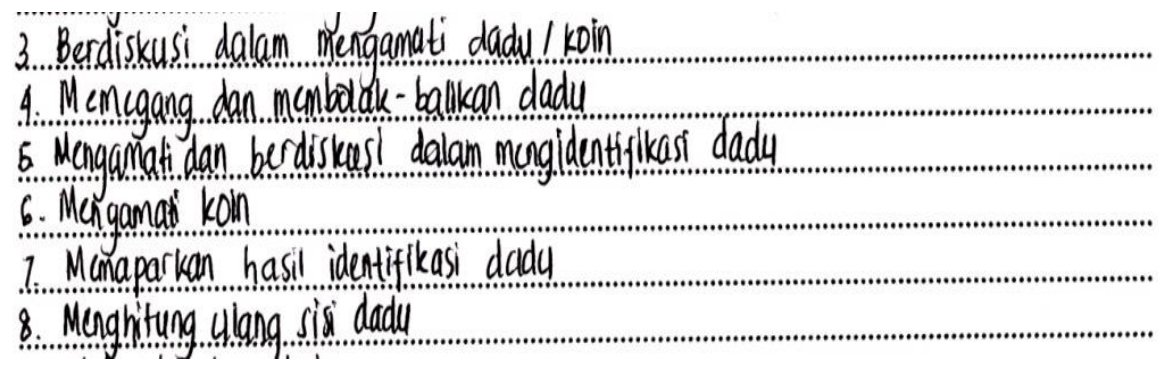

Gambar 9. Catatan Lapangan $\mathrm{S}_{9}$

Berdasarkan gambar tersebut menunjukkan $\mathrm{S}_{9}$ melakukan kegiatan mengidentifikasi dadu/koin dengan berdiskusi pada kegiatan mengamati dadu/koin, mengamati dengan membolak-balikan dadu, kemudian menghitung sisi dan rusuk dadu, hal tersebut menujukkan aktivitas berpikir kombinatorik yaitu counting processes.

Selanjutnya dalam kegiatan memaparkan hasil identifikasi dadu dan koin $\mathrm{S}_{9}$ menunjukkan aktivitas berpikir kombinatorik yaitu counting processes-set of outcomes. Hal tersebut ditunjukkan pada catatan lapangan berikut.

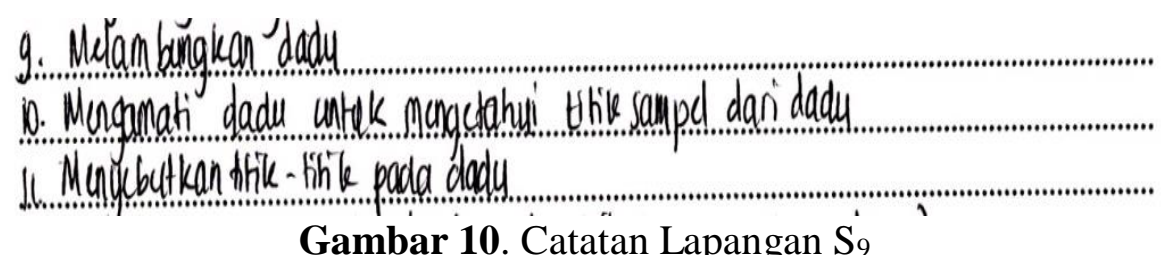

Gambar 10. Catatan Lapangan $S_{9}$

Pada gambar tersebut menunjukkan bahwa $\mathrm{S}_{9}$ sudah memahami hasil identifikasi dari dadu dan koin, hal tersebut menunjukkan adanya keterkaitan antara proses menghitung dari kegiatan mengidentifikasi dengan hasil identifikasi atau dalam model berpikir kombinatorik yaitu counting processes-set of outcomes.

Dalam kegiatan mengkonstruk titik sampel dan ruang sampel, aktivitas berpikir 
kombinatorik yang muncul adalah set of outcomes-formulas/exspressions. Hal tersebut ditunjukkan pada catatan lapangan pada Gambar 10. Gambar tersebut menujukkan $S_{9}$ menghubungkan antara hasil kegiatan mengidentifikasi dadu dan koin dalam mengkonstruk titik sampel dan ruang sampel sebagai bentuk dari formulas/exspressions. Selanjutnya dalam mengkonstruk konsep peluang secara teoritik ditunjukkan dengan cuplikan wawancara sebagai berikut.

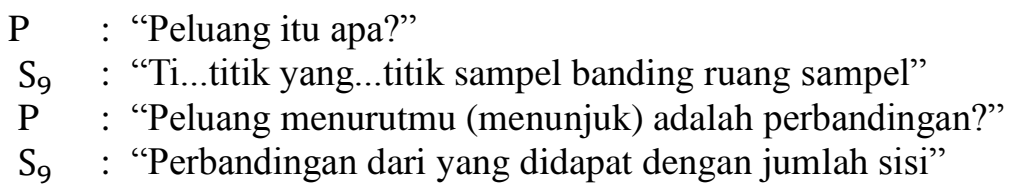

Berdasarkan percakapan tersebut menunjukkan siswa menggunakan aktivitas berpikir kombinatorik yaitu set of outcomes-formulas/exspressions. Hal tersebut ditunjukkan dengan $\mathrm{S}_{9}$ mengkaitkan hasil-hasil dari percobaan pelemparan dadu/koin dengan konsep peluang yaitu yang diperoleh banding jumlah sisi. Dalam kegiatan menyelesaikan masalah peluang teoritik dari satu/atau lebih dadu/koin. Berikut ini hasil lembar kerja $\mathrm{S}_{9}$ dalam menyelesaikan masalah peluang teoritik dengan bantuan tabel/diagram.

\begin{tabular}{c|c|c|c|c|c|c|} 
& 1 & 2 & 3 & 4 & 5 & 6 \\
\hline 1 & 1,1 & 1,2 & 1,3 & 1,4 & 1,5 & 1,6 \\
\hline 2 & 2,1 & 2,2 & 2,3 & 2,4 & 2,5 & 2,6 \\
\hline 3 & 3,1 & 3,2 & 3,3 & 3,4 & 3,5 & 3,6 \\
\hline 4 & 4,1 & 4,2 & 4,3 & 4,4 & 4,5 & 4,6 \\
\hline 5 & 5,1 & 5,2 & 5,3 & 5,4 & 5,5 & 5,6 \\
\hline 6 & 6,1 & 6,2 & 6,3 & 6,4 & 6,5 & 6,6 \\
\hline
\end{tabular}

Gambar 11. Hasil Lembar Kerja $S_{9}$

Tebel tersebut menunjukkan $S_{9}$ mampu menggunakan aktvitas berpikir kombinatorik counting processes. $\mathrm{S}_{9}$ mampu mengisi tabel tersebut dengan cara menghitung, hal tersebut diperkuat dengan catatan lapangan sebagai berikut.

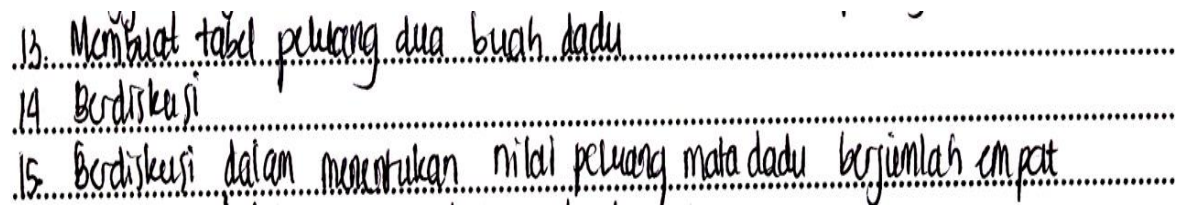

Gambar 12. Catatan Lapangan $S_{9}$

Berdasarkan catatan lapangan tersebut menunjukkan $\mathrm{S}_{9}$ berdiskusi dan menghitung hasil 
penyelesaian pada tabel hal ini menunjukkan $\mathrm{S}_{9}$ melakukan aktivitas berpikir kombinatorik yaitu counting processes. Selanjutnya dalam menyelesaikan masalah peluang teoritik dari satu/atau lebih dadu atau koin $\mathrm{S}_{9}$ menunjukkan aktivitas berpikir kombinatorik yaitu counting processes-set of outcomes. Hal ini ditunjukkan dengan percakapan pembelajaran sebagai berikut.

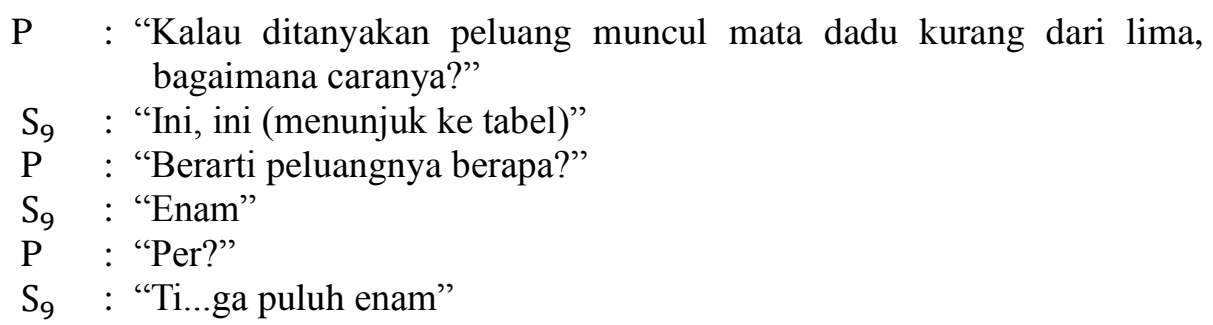

Berdasarkan percakapan tersebut menunjukkan $S_{9}$ menyelesaikan masalah peluang teoritik yaitu peluang muncul mata dadu kurang dari lima, $S_{9}$ menghitung pada tabel dan diperoleh hasil dari penyelesaian masalah tersebut.

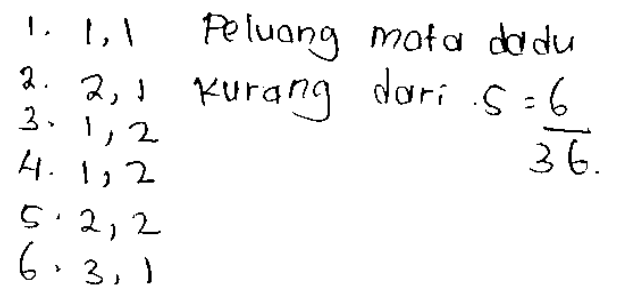

\section{Gambar 13. Hasil Lembar Kerja $S_{9}$}

Gambar tersebut menunjukkan adanya aktivitas berpikir kominatorik yaitu counting processes-set of outcomes. Selanjutnya dalam menyelesaikan masalah peluang empirik, kegiatan yang dilakukan adalah melakukan pelemparan dadu dan koin sebanyak sepuluh kali, sehingga diperoleh hasil sebagai berikut.

$\begin{array}{ll}\text { Dadu } & \text { koln } \\ 1.2 & 1 . A \\ 2.2 & 2 . A \\ 3.5 & 3.6 \\ 4.6 & 4 . A \\ 5.1 & 5.6 \\ 6.6 & 6.4 \\ 7.2 & 7.6 \\ 8.6 & 8.4 \\ 9.2 & 9.6 \\ 10.5 & 10.6\end{array}$




$$
F(A)=\frac{n(A)}{M}=\frac{3}{10}=\frac{5}{10}
$$

\section{Gambar 14. Hasil Lembar Kerja $S_{9}$}

Berdasarkan gambar tersebut menunjukkan adanya aktivitas berpikir kombinatorik yaitu counting processes-set of outcomes. Counting processes ditunjukkan dengan $\mathrm{S}_{9}$ melakukan proses penghitungan dari hasil pelemparan dadu/koin sehingga diperoleh hasil penyelesaian masalah peluang empirik yang merupakan representasi dari set of outcomes. Selanjutnya dalam kegiatan membuat kesimpulan/generalisasi dari konsep peluang menunjukkan aktivitas berpikir kombinatorik yaitu formulas exspressions. Hal in ditunjukkkan dengan gambar berikut.

$$
P(A)=\frac{n(A)}{n(S)} \quad F(A)=\frac{n(A)}{M}
$$

Gambar 15. Hasil Lembar Kerja $S_{9}$

Gambar tersebut menunjukkan $\mathrm{S}_{9}$ mampu membuat rumus matematis dari Peluang, hal ini menunjukkan aktivitas berpikir kombinatorik yaitu formulas/exspressions, rumus matematis yang dibuat oleh $\mathrm{S}_{9}$ dipeoleh berdasarkan pengetahuan yang dimiliki sebelumnya mengenai konsep Peluang.

\section{PEMBAHASAN}

Berdasarkan paparan hasil tersebut menunjukkan aktivitas berpikir kombinatorik dalam mengkonstruksi konsep Peluang. Siswa melakukan proses menghitung dalam kegiatan mengidentifikasi dadu/koin, melakukan penghitungan pada proses pengisian tabel/diagram serta dapat menyelesaikan masalah peluang teoritik maupun empirik dari proses penghitungan yang dilakukan. Berdasarkan kegiatan siswa tersebut menunjukkan bahwa aktivitas berpikir kombinatorik yang muncul adalah counting processes. Counting processes dilaksanakan pada kegiatan mengidentifikasi dari dadu dan koin, menyelesaiakan masalah peluang teoritik dari satu/atau lebih dadu dan koin, dan menyelesaikan masalah peluang empirik. Hal tersebut menunjukkan adanya aktivitas proses perhitungan atau dalam model berpikir kombinatorik disebut sebagai counting processes. Temuan tersebut sesuai dengan pendapat Lockwood (2013), bahwa siswa diminta untuk menentukan penyelesaian masalah dengan cara menghitung (counting 
processes), dan akan diperoleh generalisasi dari hasil-hasil perhitungan menjadi hasil dan rumus (formulas).

Aktivitas berpikir kombinatorik yang berikutnya formulas/exspressions. mengkonstruksi titik sampel dan ruang sampel berdasarkan hasil identifikasi dan informasi yang diperoleh dari buku, mampu memahami generalisasi dari konsep peluang berdasarkan hasil penyelesaian masalah maupun proses penghitungan dan mampu menghubungkan pengetahuan awal yang dimiliki dengan bentuk matematis/rumus matematis dari Peluang. Hal ini menunjukkan adanya aktivitas berpikir kombinatorik yaitu rumus/ungkapan pada kegiatan mengkonstruk titik sampel dan ruang sampel, mengkonstruksi peluang secara teoritik dan empirik, dan membuat rumus matematis konsep Peluang dari pengetahuan yang dimiliki sebelumnya. Menurut Lockwood (2013) bahwa siswa mampu membuat generalisasi dari hasil dan proses penghitungan menjadi sebuah rumus atau ungkapan.

Aktivitas berpikir kombinatorik yang terakhir adalah set of outcomes. Siswa mampu mengemukakan hasil identifikasi dadu dan koin, serta mampu mengetahui hasil penyelesaian masalah yang berkaitan dengan masalah peluang secara teoritik maupun empirik menggunakan aktivitas berpikir kombinatorik yaitu set of outcomes. Hal ini dilaksanakan pada kegiatan mengemukakan hasil identifikasi dadu/koin, mampu mengetahui hasil penyelesaian masalah yang berkaitan dengan peluang secara teoritik maupun empirik. Hal ini menunjukan siswa menggunakan aktivitas berpikir kombinatorik yaitu hasil (set of outcomes). Menurut Lockwood (2013) bahwa dalam siswa mampu menggeneralisasi dari kegiatan proses penghitungan menjadi hasil penyelesaian masalah. Hal ini memperkuat pernyataan bahwa terjadi aktivitas berpikir kombinatorik yaitu set of outcomes.

\section{SIMPULAN DAN SARAN}

Berdasarkan hasil penelitian dan pembahasan menunjukkan bahwa dalam mengkonstruksi konsep Peluang terdapat aktivitas berpikir kombinatorik. Counting processes ditunjukkan dengan siswa mengidentifikasi dadu dan koin, menyelesaikan masalah peluang teoritik dengan bantuan tabel/diagram, dan menyelesaikan masalah peluang secara empirik. Formulas/exspressions ditunjukkan dengan siswa mampu mengkonstruk titik sampel dan ruang sampel, mengkonstruk peluang secara teoritik, 
serta membuat rumus matematis dari Peluang. Set of outcomes ditunjukkan dengan siswa mampu menemukan hasil penyelesaian peluang teoritik dari satu/atau lebih dadu dan koin serta hasil penyelesaian masalah peluang empirik.

Dalam penelitian ini belum secara mendalam mengetahui dan mendeskripsikan komponen maupun struktur dari berpikir kombinatorik siswa dalam mengkonstruski konsep, diharapkan dengan hasil penelitian ini menjadi tonggak awal untuk melanjutkan dan mengembangkan penelitian berkaitan dengan kemampuan berpikir kombinatorik.

\section{DAFTAR PUSTAKA}

Creswell, W. J. 2017. Penelitian Kualitatif dan Desain Riset (Memilih diantara Lima Pendekatan). Yogyakarta: Pustaka Belajar.

Hamzah. 2008. Teori Belajar Konstruktivisme. Universitas Negeri Makasar: FMIPA. https://www.scribd.com. Diakses pada 31 Oktober 2018. Pukul 20.49 WIB.

Ibda, F. 2015. Perkembangan Kognitif: Teori Jean Piaget. UIN Ar-Raniry. Intelektualita Volume 3 Nomor 1, hlm. 27-38.

Lockwood, E. 2013. A Model of Student's Cominatorial Thinking. Journal of Mathematical Behavior 32 (2013) 251-265.

Moleong, L. J. 2016. Metodologi Penelitian Kualitatif. Bandung: Remaja Rosdakarya.

Rezaie, M \& Gooya, Z. 2011. What Do I Mean by Combinatorial Thinking?. Procedia Social and Behavioral Sciences 11 (2011) 122-126

Satori, D \& Komariah, A. 2017. Metodologi Penelitian Kualitatif. Bandung: Alfabeta.

Shulhany, A. 2016. Daya Kombinatorial Siswa pada Materi Peluang dengan Model Penemuan Terbimbing .Repository Universitas Pendidikan Indonesia. https://repository.upi.edu/25463/. Diakses pada 18 Oktober 2018. Pukul 18.42 WIB.

Syahputra, E. 2016. Combinatorial Thinking (Analysis of Student's Difficultes and Alternative Solution). State University of Medan. The Third Annual International Seminar On Trends In Science and Science Education, hlm. 1-13.

Widiyastuti, E \& Utami, S. 2017. Deskripsi Kemampuan Berpikir Kombinatorik Matematis Siswa. Universitas Muhammadiyah Purwokerto. Alpha Math: Journal of Mathematics Education, 3(1) Mei 2017, hlm. 58-65. 